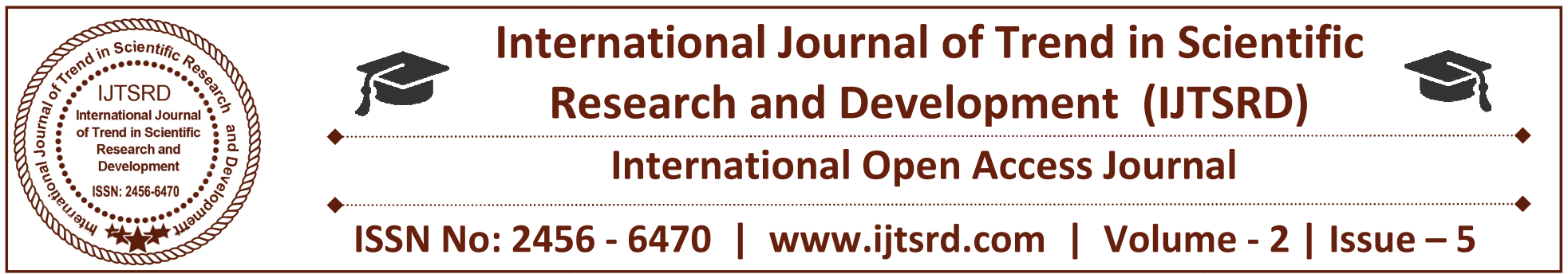

\title{
Rebranding Theoretical Aspects
}

\author{
Margarita Išoraitė \\ Associated Professor, Vilniaus Kolegija / University Of Applied Sciences, \\ Vilnius- Lt, Lithuania
}

\begin{abstract}
The article analyzes rebranding definitions, rebranding advantages and disadvantages, rebranding case analysis. Rebranding is a calculated business solution. This is a deliberate decision to improve the reputation and image of your business. A new brand identity can complement the company both internally and externally.
\end{abstract}

Key words: rebranding, rebranding advantages and disadvantages, rebranding case, rebranding importance

\section{INTRODUCTION}

Companies that do not use rebranding strategies in a timely manner often slip from competition. The importance of maintaining a strong brand image always meets the needs of consumers. That's why successful businesses continuously improve brand image by adapting to users and delivering effective messages. A successful rebranding effort is based on the concept that the brand must occupy the user's place, so that the user automatically connects the problem with a particular solution or brand, if needed
[4]. Rebranding is a process where a service or product created using a single brand or company is sold with a different brand name or identity. This includes essential changes to the brand, logo, image, advertising and marketing strategy. Typically, after a merger or acquisition, the company rebrands its newly acquired products to maintain them along with their existing product line.

\section{Definition of rebranding}

Rebranding is a marketing strategy that creates a new name, logo, design, symbol for the purpose of creating a new identity in the eyes and minds of consumers, investors, competitors. Often this is related to radical brand changes: changing the name, logo, image, advertising messages. Such changes are made to discourage negative feedback from a previous trademark or to upgrade and strengthen the brand. Rebranding is used when: the market is changing and your goods or services are no longer attractive, you bought someone else's business, just as the owner is tired of that brand, you have seen new opportunities for your business.

Table1. Definition of rebranding

\begin{tabular}{|c|c|c|}
\hline Author & Definition & Accents \\
\hline $\begin{array}{c}\text { COBUILD } \\
\text { Advanced English } \\
\text { Dictionary (2018) }\end{array}$ & $\begin{array}{l}\text { Rebranding is the process of giving a product or } \\
\text { an organization a new image, in order to make it } \\
\text { more attractive or successful. }\end{array}$ & $\begin{array}{l}\text { A product or an organization a new } \\
\text { image }\end{array}$ \\
\hline $\begin{array}{l}\text { Muzellec, L, } \\
\text { Lambkin, M. } \\
\quad(2006)\end{array}$ & $\begin{array}{l}\text { The word „,rebrands“is neologism which is made } \\
\text { up of two word defined terms. Re prefix of } \\
\text { ordinory verbs of action meaning , ,again “or „, a } \\
\text { new "implying that action is done second time. }\end{array}$ & $\begin{array}{l}\text { „Again “or ,a new "implying that } \\
\text { action is done second time. }\end{array}$ \\
\hline $\begin{array}{l}\text { Singh, A., K., } \\
\text { Tripathi, V., } \\
\text { Yadav, P. (2012) }\end{array}$ & $\begin{array}{l}\text { Rebranding is variously used to describe three } \\
\text { different events: changing name, changing the } \\
\text { brand aesthetics (colour palette, logo, etc.), } \\
\text { and/or repositioning the brand. }\end{array}$ & $\begin{array}{l}\text { Changing name, changing the brand } \\
\text { aesthetics (colour palette, logo, etc.), } \\
\text { and/or repositioning the brand }\end{array}$ \\
\hline
\end{tabular}




\begin{tabular}{|c|c|c|}
\hline $\begin{array}{l}\text { Borges, M. R., } \\
\text { Branca, A.,S. } \\
\quad(2010)\end{array}$ & $\begin{array}{l}\text { „Rebranding corresponds to the creation of a } \\
\text { new name, term, symbol, design or a } \\
\text { combination of them for an established brand } \\
\text { with the intention of developing a differentiated } \\
\text { position in the mind of stakeholders and } \\
\text { competitors. Increased competition has led firms } \\
\text { to an avenue of differentiation, and rebranding } \\
\text { has been approached by firms in order to } \\
\text { differentiate themselves and to promote the } \\
\text { corporate image. " }\end{array}$ & $\begin{array}{l}\text { Creation of a new name, term, } \\
\text { symbol, design or a combination of } \\
\text { them for an established brand with } \\
\text { the intention of developing a } \\
\text { differentiated position in the mind of } \\
\text { stakeholders and competitors }\end{array}$ \\
\hline $\begin{array}{l}\text { Juntunen, M., } \\
\text { Saraniemi, S., } \\
\text { Jussila, R. (2009) }\end{array}$ & $\begin{array}{l}\text { „Corporate re-branding is a systematically } \\
\text { planned and implemented process of planning, } \\
\text { creating and maintaining a new favourable } \\
\text { image and consequently a favourable reputation } \\
\text { for the company as a whole by sending signals to } \\
\text { all stakeholders and by managing behaviour, } \\
\text { communication, and symbolism in order to } \\
\text { proact or react to change“ }\end{array}$ & $\begin{array}{c}\text { Systematically planned and } \\
\text { implemented process of planning, } \\
\text { creating and maintaining a new } \\
\text { favourable image and consequently a } \\
\text { favourable reputation for the } \\
\text { company as a whole by sending } \\
\text { signals to all stakeholders and by } \\
\text { managing behaviour, } \\
\text { communication, }\end{array}$ \\
\hline $\begin{array}{c}\text { Conaghan, } \mathrm{T} \text {. } \\
\text { (2013) }\end{array}$ & $\begin{array}{l}\text { The word 'rebrand' is a neologism, made up of } \\
\text { the two elements - re and brand. Re is often used } \\
\text { as a prefix to denote 'again' or 'anew'. }\end{array}$ & Higlights again and new \\
\hline Luck, K. (2012) & $\begin{array}{l}\text { The reasons for rebranding are often the } \\
\text { following: } \bullet \text { competitive landscape dictating } \\
\text { further differentiation; } \bullet \text { strategic shift in value } \\
\text { proposition (new offering); } \bullet \text { relevance waning } \\
\text { or becoming outdated. }\end{array}$ & Mention the reasons for rebranding \\
\hline
\end{tabular}

\section{Rebranding advantages and disadvantages}

Rebranding is a marketing strategy in which a brand acquires a new identity in one form or another. This may include changes in the name, term, symbol, design or combination. This often includes changes to the logos, advertising themes, product packaging, slogans, and general marketing strategies. Rebranding is performed in order to survive over time, to disrupt long-term monotony, or to remain competitive. The success of Rebranding's strategy depends on planning and execution, so all factors need to be taken into account in advance. Let's look at the pros and cons of rebranding.

Table2. Rebranding advantages and disadvantages [based on 14]

\begin{tabular}{|c|c|}
\hline Advantages & Disadvantages \\
\hline $\begin{array}{l}\text { 1. Attract new customers. By focusing on } \\
\text { your image, company personality, target } \\
\text { audience, etc., you can attract new } \\
\text { customers and regain interest from your } \\
\text { existing audience. }\end{array}$ & $\begin{array}{l}\text { 1. Confusion choos. } \\
\text { Change is terrible, mainly because nobody knows what the } \\
\text { end result is. People can easily be confused and / or } \\
\text { frustrated when it changes. Publishing press releases, posting } \\
\text { ads in social media, sending emails. Communication is very } \\
\text { important during the rebranding project }\end{array}$ \\
\hline $\begin{array}{l}\text { 2. Reach new goals. Another advantage } \\
\text { associated with rebranding is that you can } \\
\text { significantly increase your efforts to reach } \\
\text { new goals. Some of your new goals may be } \\
\text { to create new products or improve existing } \\
\text { products }\end{array}$ & $\begin{array}{l}\text { 2. Clients are losing. If a suitable rebranding strategy is not } \\
\text { developed and properly implemented, you risk losing some } \\
\text { of your existing customers. Unfortunately, even if everything } \\
\text { is fine, there is still the chance to lose customers [14] People } \\
\text { do not like the changes. By explicitly explaining the reasons } \\
\text { for your rebrand and maintaining your values and } \\
\text { understanding the needs of your customers, you can reduce } \\
\text { the risk of long-term customer losses. }\end{array}$ \\
\hline
\end{tabular}


3. Increase engagement. Every time you add something new and excite your product line, or change your brand, you have the opportunity to make a big deal. You can use "rebrand" as an opportunity for people to talk about your company in social media. Instead of fearing change, you can show current and potential customers what's so great about your changes and why you're doing it.

4. Streamline messaging. Rebrand gives you the chance to get everything back on track.
3. Be ready to spend money. Be prepared to spend money on developing a creative rebranding strategy, new content, graphic design, as well as marketing and advertising campaigns to support your project. While there is the possibility of saving money through a rebrand, it is definitely worth investing some money to ensure that it is done efficiently.[14]

\section{Rebranding cases}

Coca cola case: As stated Garcia (2018) the Coca-Cola Company launching a new Diet Coke brand and a new flavor in January 2018. Diet Coke was not redeveloped, but "re-inspired" for other consumer demographics. Marketing campaign will be launched. Millennials are also highly informed by users who have access to data with their own hands through mobile devices and other technologies. The founder of the BLKBOX marketing agency, Keenan Beasley, believes that this Diet Coke Rebranding is a step in the right direction, but only the first step.

Pepsi cola case: As stated Kel (2017) „the design of the Pepsi package has contributed significantly to the brand's success. “ Kel (2017) mentioned that ,the design of Pepsi is attractive, simple and instantly visible and helps draw people's attention to drink. You can say that the design of the logo has greatly contributed to the Pepsi Cola's large soft drink brand, which is today. People can immediately associate their activities with the company logo, because they are well-designed designs that have the same color, shape and font choices. "But the Pepsi Globe logo that we see today has changed over the years. The logo journey began when Caleb D. Bradhams, the founder of the company, created a design that later came to fame. The identity of the company continued until 1940, when the company first changed the design of the logo.

As stated Kel (2017) there are some of the most important Pepsi cola logos rebranding steps (table 3).

Table3. Pepsi cola logo steps

\begin{tabular}{|c|c|}
\hline Year & Pepsi cola logo \\
\hline 1898-1940 Using the Swirly script in the logo & \\
\hline Pepsi cola logo in 1943 & \\
\hline Decade Of 1960 A Bottle Cap Design & \\
\hline Pepsi cola logo in 1990 & \\
\hline Mhe current Pepsi Globe logo & \\
\hline
\end{tabular}


Kel (2017) mentioned ,today's Pepsi Globe logo has a design that gives the smile an impression. The current logo retains its uniqueness by combining traditional colors, shapes and fonts. The shape of the spherical logo is whirling in the middle. The vortex separates the upper sheet from the bottom."

\section{Conclusions}

Rebranding can inspire a new life into your business or product, but this must be done by focusing on a strategy, a clear-cut process, a creative vision and thought, especially for good reasons. This is usually the most recognizable device used to communicate with the target audience; this sometimes means that the logo is often the only element that focuses on rebranding. [17]

\section{References}

1. Borges, M. R., Branca, A., S. (2010). The Impact of Corporate Rebranding on the Firm's Market Value. Working papers, School of Economics and Management, Technical university of Lisbon.

2. Conaghan, T. (2018). Rebranding and goodwill in the technological age.

http://www.tglaw.com.au/wp-

content/uploads/sites/3/2012/12/FCA-Rebrandingpaper-IDI-copy-Designed-Version-for-Blog-Jan2013.pdf

3. COBUILD Advanced English Dictionary (2018). Definition of 'rebranding'.

https://www.collinsdictionary.com/dictionary/engl ish/rebranding

4. Couch \& Associates (2011) The Importance of Rebranding: Keeping Your Company in Shape. http://couch.associates/importance-rebrandingkeeping-company-shape/

5. Garcia, T. (2018) Coca-Cola rebrands Diet Coke for millennials, but what's in the can may be the problem. https://www.marketwatch.com/story/coca-colarebrands-diet-coke-for-millennials-but-whats-in-thecan-may-be-the-problem-2018-01-10

6. Goi, Ch-L, Goi. M-T (2011). Review on Models and Reasons of Rebranding. International
Conference on Social Science and Humanity IPEDR vol.5, IACSIT Press, Singapore.

7. Kel, H. (2017). Pepsi Logo History \& Its Evolution $\quad$ Over $100 \quad$ Years. https://www.designhill.com/designblog/evolution-pepsi-logo-design-hundred-years/

8. Luck, K. (2012). The delicate art of rebranding: Retaining equity while creating a fresh face. HENRY STEWART PUBLICATIONS 2045855X BRAND STRATEGY VOL. 1, NO. 1.

9. Muzellec, L. Lambkin, M. (2006) "Corporate rebranding: destroying, transferring or creating brand equity?", European Journal of Marketing, Vol. 40 Issue: 7/8, pp.803-824,

10. Nunchasir, N., Udorn. P. (2015). Corporate Rebranding in Service Context: Its Effects on Relationship Strength and Future Share of Wallet. Proceedings of the Third Asia Pacific Conference on Global Business, Economics, Finance and Banking (AP15_Singapore Conference).

11. Juntunen, M., Saraniemi, S., Jussila, R. (2009). Corporate re-branding as a process. Proceedings of the 5th Thought Leaders International Conference on Brand Management, 6-7 April 2009, Athens, Greece.

12. Singh, A., K., Tripathi, V., Yadav, P. (2012). Rebranding and Organisational PerformanceSome Issues of Relevance. American Journal of Sociological Research, 2(5): 90-97.

13. Wikipedia,(2018). Rebranding. https://en.wikipedia.org/wiki/Rebranding

14. https://www.commonplaces.com/blog/the-prosand-cons-of-rebranding-is-it-worth-it

15. http://marketingovaldymas.lt/marketingas/rebrand ingas/

16. http://www.fibre2fashion.com/industryarticle/3776/why-rebranding

17. https://www.toastdesign.co.uk/the-benefits-ofrebranding/ 